\title{
Law and Culture in the Information Society
}

\author{
Branscomb, Anne W.*
}

\section{Definitions}

Culture is the manifestation of the personality of a people representing the things they hold dear.

Law is the system of rules and regulations which they employ to protect what they hold dear and to achieve the goals which they agree upon as a society should be pursued.

An information society is one in which the economic system is fueled by the exchange and productivity of information used not as ancillary to manufacturing and farming, but as a primary activity.

\section{A. Introduction}

Today consumers the world over, where citizens are permitted to make their own choices, seem to be choosing an information society. What is an information society? It is one in which the majority of the people are engaged in the creation, gathering, storage, processing, or distribution of information not in agriculture, or manufacturing. Already it is estimated that more than $60 \%$ of the U.S. work force is engaged in such activities, and it is estimated that $40 \%$ of the world labor force will be so employed by 1990 . The 1900 United States census found $37.5 \%$ of the population engaged farming activities and only $17.61 \%$ as white collar workers; the 1980 census found only $2.8 \%$ of the population still farming while $52.2 \%$ are white collar workers. (1) By comparison the People's Republic of China still has about $69 \%$ of its population engaged in agricultural activity (see Diagram A for comparison with other countries).

An information society is not economically independent, unless it uses the fruits of its information productivity to increase its agricultural or industrial production and absorbs the displaced agricultural and industrial workers in

* Attorney at law

(1) - Statistical Abstract of the United States, Washington, D.C.: GPO, 1984 
Diagram A 1980 Labor Force From World Bank ${ }^{(2)}$

\begin{tabular}{lccc}
\hline & Agriculture & Manufacturing & Services \\
\hline United States & $2 \%$ & $32 \%$ & $66 \%$ \\
Singapore & $2 \%$ & $39 \%$ & $59 \%$ \\
Japan & $12 \%$ & $39 \%$ & $49 \%$ \\
Brazil & $30 \%$ & $24 \%$ & $46 \%$ \\
Korea & $34 \%$ & $29 \%$ & $37 \%$ \\
P.R. China & $69 \%$ & $19 \%$ & $12 \%$ \\
\hline
\end{tabular}

the generation of information products and services. If it is unable to provide full employment for its citizens who are displaced by such economies in productivity, it must find a methodology for sharing the fruits of the information activity without creating an underclass to foment turmoil and dissatisfaction. A pure information society must seek agricultural and industrial support from other societies, even as such agricultural and industrial societies must seek technology transfer from information societies.

However, information societies have more economic wealth than agricultural and industrial societies. This trend correlates with the number of telephones available to the population(although the cause and effect have not been proved). This phenomenon has not escaped the notice of developing countries. They too want to enjoy the increased affluence which the harnessing of information technolgy makes possible (see Diagram B for comparisons of telephones and economic productivity). ${ }^{\text {(3) }}$ These figures also correlate with an extremely high literacy rate. ${ }^{(4)}$

An agricultural or industrial society can afford to give away information, because it increases the productivity of its basic economic activities. An information society cannot afford to give away information, because that is the basic commodity which it must use to bargain for consumer goods in the international marketplace.

(2) World Bank, World Development Report, Oxford, U.K.: Oxford Univ. Press, 1983. Table 21, Labor Force p. 188-9.

(3) "Correlations Between Telephone Densities and GNP per capita for selected countries", ITU, World Communications 40-41, Novara, Italy: Le Monde Economique.

(4) World Bank, supra, note 2, Table 1, Basic Indicators, 148-149. 
Diagram B

\begin{tabular}{lcll}
\hline \multicolumn{1}{c}{ Country } & $\begin{array}{c}\text { No. Telephones } \\
\text { per 100 Pop. }\end{array}$ & $\begin{array}{c}\text { GNP } \\
\text { Per Capita }\end{array}$ & $\begin{array}{l}\text { Per Capita } \\
\text { Income }\end{array}$ \\
\hline 1) United States & 83.7 & United States & Switzerland \\
2) Sweden & 79.6 & Sweden & Sweden \\
3) Suisse & 72.6 & Suisse & Norway \\
4) Canada & 67.6 & Canada & Germany \\
5) Denmark & 63.6 & New Zealand & Denmark \\
6) New Zealand & 56.8 & Denmark & United States \\
7) Australia & 52.6 & Finland & France \\
8) Netherlands & 50.9 & Australia & Belgium \\
9) United Kingdom & 49.7 & United Kingdom & Netherlands \\
10) Finland & 49.7 & Japan & Canada \\
11) Japan & 49.4 & Netherlands & Australia \\
12) Germany & 46.3 & Germany & Finland \\
13) France & 45.2 & & Austria \\
14) Norway & 45.2 & & Japan \\
\hline
\end{tabular}

\section{IMPACTS UPON GOVERNANCE}

There are profound impacts upon governance in the information society that are only recently becoming apparent.

First, information technology is both revolutionary and democratizing. (5)

Second, an information society requires consensus rather than coercive leadership. ${ }^{(6)}$

Third, power will become decentralized and shared in governmental as well as business organizations. ${ }^{(7)}$

Fourth, global strategies dominate regional and parochial interests. ${ }^{(8)}$

(5) Chace, Susan, "Radical Chip", Wall St. Journal, Jan. 18, 1983, p. 1.

(6) Ogle, James V., “Will Computers Destroy the Soviet System?”, Washington Post, November 1, 1981, C-1; Lerner, Max, "When the microchips are down, it's still the same old Soviet”, New York Times, January 2, 1986; Cleveland, Harlan, "How Leaders Must Change in the Information Age, Christian Science Monitor, February 16, 1981, p. 27; Masuda, Yoneji, The Information Society as Post Industrial Society, (Bethesda, MD: World Future Society, 1981); Cleveland, Harlan, The Knowledge Executive, New York, NY: E.P. Dutton, 1985.

(7) Naisbitt, J., Megatrends, quoted in Hacker, A., “A Trendy View of Trends", Forlune, December 27, 1982. 
Most nations that are becoming information societies are industrial democracies. They find that the general availability of information resources to the public accelerates the decentralization of governance. Authoritarian societies seeking to become information societies may find that they must suppress the distribution of information technologies in order to maintain centralized control. Othewise they may have to experience the same revolutionary and democratizing effect of information technology in order to participate in the benefits of a global information economy.

\section{B. Implications for Public Policy}

What do these macro impacts upon us translate into as concerns for the development of a sensible public policy?

\section{We must redefine what we mean by work.}

Primary economic activities will be in sectors which are currently considered "leisure" or "entertainment" or "politics" or "philosophy". Intellectual productivity will be predominant over manual dexterity and physical strength. Thus we must begin to reorient our national accounts to take into consideration the contributions made by the intellectual work force to the gross national product. We must also adapt our information gathering to reflect the demographic data accurately so that the most productive sectors of our economy are adequately recognized and serviced by national policies.

\section{We must place greater emphasis upon education.}

This is not merely in order to create better opportunities for those who are becoming obsolete in their manual skill within an information economy. Education must be emphasized not merely as a secondary activity to supply skilled workers to the work force. It has become a primary activity whose only end and purpose is for itself. Education as a primary consumer product for self fulfillment and enjoyment becomes a major economic activity. The development of, investment in, and deployment of human resources becomes a major factor in maintaining a competitive edge over world trading partners.

(8) Dalfen, C., Keynote Address at the Conference on Transborder Data Flow, the Intergovernmental Bureau of Informatics, Rome, 1980. see also, Cleveland, supra note 6 . 
Thus information societies invest their intellectual capital at least as wisely as they invest their financial capital.

\section{An open and available global telecommunications system is essential to survival.}

The mass media have become the environment in which international public opinion is formed and the outer limits of public decisions are set. To reach consensus among the far flung communities of the world and between such geographically dispersed governing units, will place a much greater burden upon our telecommunications systems to achieve global consensus.

\section{Cultural Biases in the Legal System}

The means to deal with these macro impacts are territorially limited, and cultural differences inhibit our ability to cope with globally acceptable alternatives. Cultural characteristics are the very core of a legal system. Laws reflect ethical values. For example, the attitude towards intellectual property differs greatly from a capitalistic to a theocratic society. Indeed, the term property itself is alien to a theocratic society. In the middle ages scribes laboriously produced manuscripts for the glory of God. The social institutions within which they lived-monasteries and nunneries-provided the simple needs of life. Since talents and skills were God given, they were to be used for the glory of God. Rewards were to be in the hereafter and not in the here and now.

Within a capitalist society, intellectual productivity is a marketable commodity which has economic value. In an information society in which more than $50 \%$ of the economic activity is related to information gathering, distribution and exchange, it would be unrealistic to expect the economy to survive if none of these activities were financially rewarded.

We live in a world which includes many different kinds of societies. Even within the same nation we have conflicting views of how information should be treated as a marketable commodity or a basic resource. We treat different kinds of information differently. For example, strategic information is tightly protected while hurricane warnings are disseminated widely as a public good. Thus there are many complex issues which must be considered in determining whether a society wishes to become an information society or remain an 
agricultural or industrial one. There are also many public investments which must be made in hardware, software, and legal systems if a global information society is to flourish.

In short it is imperative that we sort out what we can expect to achieve within the clash of cultural values and legal norms to survive within the Information Age.

\section{Information Rights and Obligations}

In a society in which information is a basic resource fueling economic productivity, who is entitled to use what information for what purposes? Indeed, who is required to make available what information to whom? Clearly we must establish universally recognized principles concerning the collection, exploitation, and utilization of data.

\section{The right to collect and use data}

Personal data is the raw material of demographic data which is absolutely critical to the decision making process of businesses, nations, and charitable institutions. To withhold individual or corporate data distorts and destroys the value of generic or collective data. Thus to insure that statistics are accurate we must establish obligations to release information in order to guarantee that the value of demographic data is not impaired. Yet we must also insure that the privacy of individuals and corporations will not be breached. Personal data must be protected when it is likely to damage the persona or psyche of the individual. Much effort has been expended on establishing legal rights in computerized data bases. Within the United States and Twelve Western European conutries, the United States, Australia, Canada, Israel, and New Zealand have enacted legislation. (9) OECD has promulgated guidelines, and a convention of the European Community has been opened for signature by member nations. ${ }^{(10)}$ The various statutes and documents vary but most contain certain basic principles of privacy which include(11):

(9) "Data Protection Becoming Worldwide", Transnational Data and Communications Report, January 1986, p. 29.

(10) OECD, Paris, France, adopted September, 24, 1980: Council of Europe Convention, Strasbourg, France, adopted and opened for signature, September 18, 1980.

(11) For a good introduction to the issues, see Yurow, Jane, "Data Protection", in Branscomb, A.W. ed., Toward a Law of Global Communications Networks, White Plains, NY: Longman, 1986. 
- limitations on the collection of personal data

-reqirements that the data be relevant, accurate, timely

-notice of the purpose for which the data is collected

- limitations on disclosure without the consent of the subject

- protection against unauthorized use of the data

-open policies and practices

-rights of the subject to review, challenge, and correct data

\section{The right to protect data against disclosure}

Much of the data which is collected by large institutions and which has high economic value is collected by companies to which such information is disclosed in exchange or a quid pro quo for offering a specific service-medical treatment, a mortgage for a home, an insurance policy, etc. Thus the information is released by the source with the expectation that the information will not be disclosed to third parties. However, there is often no legally enforceable right to prevent such disclosure and the information in the hands of the institution to which it is disclosed is often deemed to be the owner of its records-for example, there is a holding in the U.S. to the effect that bank records belong to the bank not to the account holder. ${ }^{(12)}$ They may be released to police and security authorities. May they also be sold to retail merchandisers?

Most banks operate under an ethical mandate not to disclose the details of their customers accounts. Indeed, in Switzerland, numbered bank accounts protect the identity of the holder. There may be transnational interests which require such knowledge in the pursuit of nationals attempting to avoid taxation of their assets. The recent disclosure by Swiss authorities of financial assets deposited in bank accounts held in the name of Ferdinand Marcos and his wife to Philippine authorities was the first time such breach of confidentiality has been made. ${ }^{(13)}$ Where do the equities fall? What should the national and international law be governing such a situation?

a. Personal Data

The right of privacy must be protected in releasing information to national statistical data bases such as the census. Although the release of individual

(12) U.S. v. Miller, 425 U.S. 435 (1976).

(13) Dow Jones News, Document 860404-0040, Wall Street Journal, April 4, 1986, p. 10. 
data could be damaging to the individual, to withhold such data from national statistics will distort the analysis and lead to imperfect decisions. Therefore, it is imperative that all citizens be required to give accurate and full data to the national accounts but that the individual data should never be released in a form which is recognizable as pertaining to the particular individual.

Cable Television has great potential for both benefits and abuses. The technology has the potential to monitor choices which will greatly refine the maketplace for consumer goods as viewer habits are translated into consumer purchases on interactive cable television systems. The potential for enhancing the political process is immense as interactive systems can supply immediate feedback to political representatives without waiting for structured national polls. The discussion can be in real time and with representatives of the people in direct contact with their constituents. Yet individuals must be protected from disclosure by a cable television system of individual predilections, purchases, or viewing patterns which reveal personal political choices and lifestyles which might be embarrassing or deleterious to their reputations. However, Cable Communications Act of 1984 contained a provision requiring cable television companies to notify customers of the information which is offered to third parties and to permit their subscribers to prohibit such distribution if they wish to do so. The treaty among the Lander of Germany similarly prohibits the collection of individual data from subscribers to the cable television services and Bildschirmtext other than that necessary to collect payment for individual programs or pages of text accessed by the consumer. ${ }^{(14)}$

Medical data where correlated speeds up knowledge of epidemics, nutritional inadequacies, environmental hazards and aids in the analysis of causal connections. Yet disclosure of individual medical records may reveal homosexuality or other impediments to employment, access to insurance policies or social acceptance in the community. Individuals who are apprehensive about disclosure of their personal records should not be permitted to impede medical progress by withholding access to their records for statistical and scientific analysis. However, a caring society will protect fully the information contained in medical records. ${ }^{(15)}$

(14) Cable Communications Act of 1984, P.L. 98-549; 98 Stat. 2779. Treaty on Bildschirmtext, 18 March 1983.

(15) Family Educational Rights and Privacy Act, 20 U.S.C. Sec. 1231g 


\section{b. Corporate Data}

Multinational Corporations which operate in many countries rely upon rapid telecommunications systems to exchange data among its many corporate sites. The right to transfer such data without interception, or disclosure is a necessary corollary to a healthy business operation. Much of the information is proprietary or internal to management decisions and disclosure may reveal corporate strategies to competitors. Also many multinational corporations are quite concerned about the application of Right to Information Laws being applied to corporations. If a corporation had the right to examine and correct information contained in the files of a corporate competitor, then it would be able to penetrate strategic data which would give it a competitive advantage. (16) Thus the rights of multinationals to keep secret their strategic planning is essential to business success. Furthermore, laws which inhibit MNC's from transferring information about nationals outside the country of origin may affect the career advancement of those nationals within the company if their records are not intermeshed with those of employees of all countries in which the MNC is operating. ${ }^{(17)}$

Thus corporate rights in the protection of privacy of their own corporate data is as important as the right of governments to obtain corporate data for aggregate economic analysis and statistical data about the business community. How you balance these conflicting interests is an area of considerable concern as more data is massaged by a greater number of information providers. How you guarantee the accuracy of data is also a question of great importance.

c. National Data

Nation states claim the right to privacy. It is called cultural sovereignty. Nation states which confront the problems of remote sensing of their natural wealth by satellites claim a legal right to release such information only to those whom they choose and at a price which will benefit their own citizens, not only those who are able to exploit it. They proclaim that remote sensing is an invasion of sovereign rights over their geopolitical space. They suggest that any use of information obtained by remote sensing denies the local nation-state and its nationals the right to derive economic benefit from

(16) Maisonrouge, J.G., "Regulation of International Information Flows", 1 The Information Society 17 at 22, 1981.

(17) Schaeffer, F.W. Dietmar, "Human Resources Information Systems", ch. 12 in Branscomb, supra note 11 . 
exploitation of their own economic resources. As such nations have no physical means of preventing remote sensing, they must assure such protection by legal means. ${ }^{(18)}$

Protection of cultural preferences are high on the list of priorities of many countries. Even the United States, which preaches "free flow" of information, labels Canadian films on nuclear power as "propaganda". (19) As the United States population is an amalgamation of many different cultures, the U.S. has no constitutional mechanism for containing its culture or conforming it to any norm. The U.S. Constitution preserves freedom of choice to follow whatever lifestyle or cultural preference each person chooses. Thus the unique cultural roots of the U.S. lead it into constant confrontation with those countries which seek to preserve the integrity of their own cultural background through the establishment of content controls. Here is an area in which the law and the culture are in greatest conflict. The U.S. hopes that those who wish to protect their own cultural heritage will do so through the power of persuasion rather than coercion. An open information transport system through which the many cultural choices are available to all is a necessary mandate for an information society. Since information boundaries cannot be closed except with the most rigid authoritarian and coercive controls, choice and consensus must be pursued within the communications system.

\section{Right of access to information}

\section{a. Rights of the Press}

There are a number of rights which are being urged upon the global community. There are the rights of the press to obtain information from the government and/or from illicit sources which journalists latter wish to protect from disclosure. ${ }^{(20)}$

(18) Moore, G., "Earth Resources Satellites: A Puzzle for the United Nations", 16 Harv. Int. L. J. 648 (1975).

(19) “U.S. Seeks to Mark Films Not Approved", Denver Post, February 25, 1983, p. 1-A, 7-A; see also 100 Christ Century 240-1, March 16, 1983.

(20) See Dawson, S.A., Freedom of the Press: A Study of the Legal Doctrine of Qualified Privilege, Rothman, Littleton, Colorado 1982. See also Goodale, James C. "The Tavoulearas Jury Verdict Provides a Chilling Lesson for the Press" and Heinke, Rex. S., “Added Damages for Publication Should Not Be Available in Intrusion-Trespass Cases Without Independent Justification", Communications Lawyer, Summer 1983. 


\section{b. Rights of Individuals}

There are the rights of individuals to government or corporate files in order to know what is being archived and an opportunity to correct such files. In the United States only government files are subject to disclosure to individual requests. As the information societies produce larger and larger numbers of data bases and files which contain information which, if inaccurate can affect the lives and fates of all citizens, the clamor to open up private files to some corrective measures will increase. ${ }^{(21)}$

More important in information societies is the right of access to information upon which public decision making is based. ${ }^{222}$ In a truly open information society withholding too much data under the guise of secrecy leads to a lack of public confidence upon which public consensus in built. As more and more citizens have their own microcomputers and their own modelling programs, they will expect to have a more open access to the information available to public officials in order to share the responsibility for right decisions. A collegial form of leadership demands a wide data base open to all participants.

\section{c. Rights of Governments}

Certainly, there are also rights of governments to obtain strategic and economic information which, if not established by legal means are certainly established by the power of discovery. No one questions the "spy satellites" which roam the sky. However, if all the nations of the world put such satellites into orbit, the clutter would become unbearable. The establishment of global surveillance satellites would provide the necessary data for the preservation of peace by the world community of nations. ${ }^{(23)}$

The same is true of remote sensing. A global system of remote sensing satellites and weather monitors would provide the world community with a system of global resource information which would be financially supported by all and available to all. ${ }^{(24)}$

(21) Privacy Act of 1974, 5 U.S.C. Sec. 552a; Family Educational Rights and Privacy Act, 20 U.S.C. Sec. 1231g, 20 U.S.C. Sec. 1231g g; The Tax Reform Act of 1976, 26 U.S.C. Sec. 7609; The Right to Financial Privacy Act, 12 U.S.C. Sec. 3401, et. seq.; and the Fair Credit Reporting Act, 15 U.S.C. Sec. 1681.

(22) Jones, Mary Gardiner, "The Challenge of New Information Technologies: The Need to Respond to Citizens Information Needs", 2 The Information Society 145 at $153,1983$.

(23) The French were the first to suggest such an arrangement.

(24) U.S. National Academy of Sciences, Ad Hoc Committee on Remote Sensing, 
There is also a growing concern by governments that other governments should disclose to the world community information about accidents, natural disasters, or threats to public health. This concern has been highlighted recently by the explosion of a nuclear reactor at Chernobyl near Kiev in the Soviet Union. Western European nations were shocked that they had to learn of the disaster from non-Soviet sources which were monitoring the level of radiation in neighboring countries. As a consequence the Tokyo economic summit promulgated a statement urging timely disclosure of such information. ${ }^{(25)}$

\section{The right to prevent distribution of information}

As the amount of information available grows more and more intense, there will be a greater and greater concern for legal means to prevent the distribution of information which is unwanted or redundant. Already trash baskets overflow with unread magazines, unread newsletters, and unread catalogs. Often there are several copies of the same document addressed to several different versions of the same name which some unskilled key puncher has mangled unrecognizably. The U.S. Postal Service is required to stop pornographic mail at the post office if the addressee signs a special order declaring a desire to be protected from this particular correspondence. ${ }^{(26)}$ Although the direct mailers association promises to remove a person's name from all lists if requested, few people want to be removed from everything. Petitions have been filed with the Federal Communications Commission, as yet unsuccessfully, to curb the proliferation of "junk" telephone calls or unwelcome solicitations which are facilitated by automatic telephone dialing machines. ${ }^{(27)}$

1977. See also, Schiller, H., "Remote Sensing by Satellite: Global Hegemony or Social Utility", Gerbner and Seifert, eds., World Communications, White Plain, NY: Longman 1983. UNCTC, Transborder Data Flows: Transnational Corporations and Remote-Sensing Data, New York, NY: United Nations, 1984.

(25) "Texts of the Statements Adopted by Leaders of 7 Industrial Democracies", New York Times, May 6, 1986, A-12. "Each country, furthermore, is responsible for prompt provision of detailed and complete information on nuclear emergencies and accidents, in particular those with potential transboundary consequences."

(26) Rowan v. United States v. Post Office Dept., 397 U.S. 728 (1970).

(27) Baer, Walter S., "Enhancing Personal Control of Communications", Paper Presented at the World Communications Conference, Annenberg School of Communication, Philadelphia, Pennsylvania, May 11-14, 1980; FCC Docket no. $78-100$, RM 2955. 
A more recent concern is the clutter within electronic message systems of unwanted electronic messages. Whereas the unwanted posted letter may merely fill the trash basket and put a greater burden upon garbage collection, unwanted electronic messages may exhaust available space for preferred messages, put a financial burden upon the recipient and/or slow down the message retrieval process. However, the basic principles are the same that individuals should not be forced to read messages which they do not desire to read unless they are related to public safety or the integrity of the message system itself. This is an area for fertile exploration in the future.

Just as there is a delicate balance between the protection and disclosure of strategic information, there must be developed a sensible legal solution to the information "overload". In order to develop protective laws it will be necessary to recognize some property interest in information about oneself, which gives one the right to authorize or withhold disclosure.

\section{The right to reply}

The right to reply is one which is both necessary and troublesome. In a system with limited space or channel capacity, the voice of the "loyal opposition" has often been assured through legal and/or voluntary means. In the British Broadcasting System time is allocated during elections to the political parties to appear before the electorate. In the U.S. the Communications Act of 1934 provides "equal time" to candidates for public office and an opportunity for those personally attacked by the broadcast media to reply, ${ }^{(28)}$ although newspapers have never been subjected to any legal right of reply. ${ }^{(29)}$ Such legal restrictions have proved troublesome. The press constantly attempts to have them withdrawn arguing that an open and unrestricted system of full argument from all advocates is far preferable than one which attempts to provide legal redress for specific grievances. No doubt they are right from a philosophic standpoint, but it is an economic reality that dissident groups often have difficulty in obtaining access to the press particularly in societies which exert substantial content controls. Many countries do provide an opportunity for injured parties to obtain space for replies in the regulated media.

An interesting corollary is to be found in the claims of Third World cou-

(28) 28 U.S.C. Section 315, CBS v. DNC, 412 U.S. 94 (1973).

(29) Miami Herald v. Tornillo, 418 U.S. 241 (1974). 
ntries to an opportunity to reply to coverage in the world press of their politics, culture and economies. ${ }^{(30)}$ However, given the lack of enthusiasm in the developed countries for Press Councils which might offer opportunities for correction and impose obligations upon the press for retractions of inaccurate published material, the prospects of such rights being imposed in the near future are not promising. Nonetheless, there will continue to be much ferment concerning the right of reply. Information societies cannot tolerate a closed system in which dissident groups cannot find an avenue for the dissemination of their views. Such societies are predicated upon an open and fluid circulation of all points of view. If such a system cannot be achieved without mandatory requirements, then the philosophical mandates, economic equities, and technological capabilities must be reconciled through the legal system.

\section{The right to derive value from information}

There are major transformations concerning legal protection of property rights in information based upon the increased value of information in an information society. Several examples will suffice to illustrate the right to exploit information.

a. Entertainers

Consider the case of Elizabeth Taylor who sued ABC for an injunction against producing a docudrama on her life in which she had no participation and no financial interest. ${ }^{\text {(31) }}$ Her theory was that she had a proprietary interest in the story of her life. Certainly the docudrama had economic value. Indeed, all of her own efforts had gone into building up the economic value in her persona through her performances in motion pictures. Not only did she claim a right to control the distribution of information from that economic capital but to derive income from such distribution.

b. Public Officials

The question also arises when a public official leaves office and accepts a contract to write a book or a consulting fee from a news organization or

(30) Report by the International Commission for the Study of Communication Problems, Many Voices, One World, London: Kogan Page, New York: Unipub, Paris: UNESCO, 1980.

(31) Kovner, Victor A., "The Great Docudrama Controversy-Elizabeth Taylor and ABC", Communications Lawyer, Spring 1983, p. 1. See also Elizabeth Taylor v. American Broadcasting Companies, Inc., et al. 82 Civ. 6977(S.D. N.Y. 1982) and Davis, et al. v. Costa-Gravras, 83 Civ. 0019-A (E.D. Va. 1983). 
network. Should a public official derive income from information obtained during public service? Should a public official be able to control the distribution of information which is the foundation of public decision making in order to make a personal profit?

The question was put recently in the case of Richard N. Perle, Assistant Secretary of Defense, whose controversial offering to publishers of or a proposed novel which precipitated bids of up to $\$ 300,000$ before it was halted. "Memoranda" proposed to disclose insights into sensitive security matters in a well known controversy between Perle and an Assistant Secretary of State. Several Senators criticized Perle's proposed novel as exploitation of his tenure as a public servant as well as "chilling" policy recommendations of other public officials who might not want to see their behavior chronicled subsequently in a novel. Perle defended his position by saying that he did not intend to write the novel until he left office. ${ }^{(32)}$

Presidents often sell their memoirs of historical public engagements in the multimillions of dollars. There are conflicting interests which have to be reconciled in an information society concerning economic incentives for the packaging and distribution of legitimate information which is desirable and necessary and the allocation of economic value for such processing. In the case of the public official, should not the public which put that official into office have some economic interest in the information if it has value? On the other hand worldwide we permit and encourage musicians and actors to derive income from their performances and often compensate them in the multimillions of dollars for their performances and sporting feats. Perhaps the high performers in public affairs should also be financially compensated according to the public approbation? Different cultures will arrive at different conclusions on these questions, and their laws will reflect these differences.

c. Criminals

More troublesome is the question whether or not a criminal should derive income from the exploitation of information about his or her criminal activity. In New York, the case was brought to public concern in the Son of Sam case. As a result there are now a number of so-called Son of Sam laws in many states prohibiting a person convicted or a criminal offense from

(32) New York Times, April 12, 1986, p. a-5; Dow Jones News Service no. 860412-0014, Washington Post article by Marjorie Williams, April 12, 1986, Style-1; Document no. 860411-0081, Washington Post article by Marjorie Williams, April 11, 1986, Style-1. 
selling that story. ${ }^{(33)}$ This is a good example of the macro impacts of the legal treatment of information. If the criminal is permitted to exploit the information about criminal activity, does it not provide economic incentive to commit criminal acts?

The public official defends his behavior on the basis that the information will not be disclosed or exploited until he is out of office. However, the criminal dose not intent to tell his story either until he has completed the crime. Wherein lies the difference in protecting the integrity of information and the discharge of public office?

\section{d. Nations}

Another aspect of information value is in the sale of information from remote sensing. Originally, this information was obtained by LANDSAT satellites put in orbit by the U.S government, and financed by public funds. The information was processed by a government agency and sold for an incremental but negligible cost which did not reflect the cost of research and development or even of the full cost of operating the satellite system. However, with the transfer of such remote sensing to private enterprise and the entry of the French SPOT satellites-this information is being sold at higher prices but with less control over the content being released. ${ }^{(34)}$

There are at least three legal issues which require resolution: 1) the question of the right of the source of the information to prohibit the sensing or to derive economic benefit from its release: 2) the availability of sensitive national security information to widely dispersed and non-governmental agencies: and, 3) the rights of individuals to prevent the distribution of information so obtained. If the pictures are so precise that they can read the numbers on an automobile tag, then pictures of a nude beach could be taken by satellite and published. Take the case of Jacqueline Kennedy Onassis, in which the court ordered the "paparazzi" (media photographers) to stay a reasonable distance away from her with their cameras. ${ }^{(35)}$ This decision would be rendered incompetent to protect her privacy if the camera in the eye in the sky can produce a publishable replica from outer space.

(33) According to the Christian Science Monitor, April 5, 1983, p. 1, fifteen states had passed "Son of Sam" laws freezing the proceeds from money making ventures such as book sales until the claims of victims of their crimes were satisfied.

(34) Broad, Wm. J., "Civilians Use Satellite Photos for Spying on Soviet Military", New York Times, April 7, 1986, p. A-1.

(35) Galella v. Onassis, 487 F.2d 986 (2d Cir. 1973). 
Thus information technology is rendering many of our protective laws inadequate - as in the case of the 12 mile boundary for nation states. This was based upon the ability of canons to prevent ingress within the 12 mile range of their batteries ${ }^{(36)}$ - a distance long since shattered by weapons with greater range and power. The advent of the "star wars" satellites will similarly shatter the mandate to keep space open only for peaceful purposes.

e. Individuals

There is economic value in a person's name and address. The direct mail sales in the United States alone were $70 \$$ billion in 1985. Direct mail marketing enjoys a $10 \%$ growth rate and is expected to constitute $25 \%$ of all retail sales by the end of the decade. ${ }^{(37)}$ This trend is based upon a number of factors. More women are working and find it more convenient to order from catalogs than to spend time shopping: and more people are living longer with less mobility. However, the success of direct mail marketing is also dependent upon a telecommunications infrastructure which can deliver a catalog, or video offering via television or videotape, can transmit the order via telephone or post and then deliver the consumer product.

What is valuable in this context is the availability of names and addresses of potential customers and particularly their buying habits. Consequently, sources of such information are in high demand-magazines which are connected to specific buying preferences-golfing, tennis, real estate, financial news. Businesses which have such information can derive substantial incomefor example, the Reader's Digest, which estimates the value of its mailing list of seventeen million subscribers at around $\$ 7$ million annually, refuses to sell its lists-in order to protect its clientele. ${ }^{(38)}$ On the other hand, Sigma $\mathrm{Xi}$, which is a professional orgnization of 120,000 scientists derives $\$ 65,000$ annually from the sale of address labels of its membership. Sigma Xi considers the marketing of its lists a good source of income which can be deployed productively in pursuit of its own institutional mandate. ${ }^{(39)}$

If a person's name and purchasing habits or travel plans, financial capabilities, or special viewing interests are of such value, should that person not have a right to authorize the sale and/or collect a royalty on the use by third parties? To do so would require recognizing such information as prop-

(36) Baty, “Three Mile Limit”, 22 A. J. Intn'l L. 503 (1928).

(37) Today Show on NBC, April 2?, 1986.

(38) Information obtained from conversation with CEO of Reader's Digest.

(39) Information obtained from President of Sigma Xi. 
erty. ${ }^{(40)}$ This is an area, which even in the most developed information societies has not yet been fully explored.

In summary, to develop and protect a diversity of proprietary interests in information these conflicting interests must be reconciled:

(1) How to compel disclosure and insure the accuracy of data required for public decisions:

(2) How to protect the legitimate concerns for confidentiality of sources of information;

(3) How to reward the creators and distributors of intellectual products for their efforts:

(4) How to accelerate the absorption of human knowledge to fuel the growth of the information economy.

\section{E. Domestic Jurisdictional Issues}

\section{Medium and message-mixed or separate?}

A major problem in many countries is how to reconcile the bifurcation of content or media related law with the law of the telecommunications or information transport systems. In many nations, we are moving toward the integrated services digital networks (ISDNs) in which text, voice, and video messages can all be carried over the same lines and accessed through the same termiral. At the same time we are moving toward removing the legal barriers which we have constructed between what we call broadcasting and what we call telecommunications (telephone, telex, and telegraph).

Take, for example, the NEW YORK HERALD TRIBUNE, which is printed simultaneously in seven cities from Paris to Hong Kong. This is a newspaper, broadcast over a satellite system, in a point to point mode-which could be picked up by satellite antenna without authorization, unless encrypted. In this operation alone, we find many of the legal questions which arise from the confrontation of the technical capability, the economic constraints and opportunities and the cultural restrictions as expressed in our legal systems. Originally organized as an English speaking newspaper for Americans living in Paris, it has become an international source of information about the collective countries in which it is distributed. Asked whether or not they

(40) Nimmer, The Right of Publicity, 19 Law \& Contemporary Problems 836, at 209 (1954). 
would want a local edition, especially written for their locale, subscribers overwhelmingly expressed a desire for a centrally assembled newspaper which would combine inputs from all of these sources. Those who live in Hong Kong want to know about markets in Brussels, and vice versa. Thus a more balanced carriage of news resulted from this choice of content. However, those who are concerned about the centralizing affect may be concerned that each edition did not more thoroughly reflect the cultural values and news of the area in which it circulated. (41)

\section{Market entry for non-domestic video services}

This becomes an even more critical concern with the cross cultural impact of satellite delivered broadcasting signals such as the Skychannel service which is delivered to European cable television systems. This is a problem long known to the Swiss, which carry French and Italian broadcast stations but is becoming a worldwide problem as videocassettes begin to circle the globe even in countries which seek to impose strict prohibitions upon their import.

\section{Content controls}

Even more likely to cause concern about cultural content is advertising and entertainment program content. Cultures which abhor the use of alcohol and keep their bodies well covered are offended by the appearance of alcoholic beverages on the video screen and the showing of flesh. ${ }^{(42)}$ Yet, as the channels of communications proliferate, the economics of program production dictate more centralized programming in order to amalgamate sufficient funds to produce quality programming. Despite cultural controls which place limitations upon the percentage of programs which can be imported, strains are put upon the domestic production capacity to produce sufficient programs for the domestic market. Consequently, many program producers from various countries must look to the syndication market or to foreign distribution in order to fund up front the initial production costs. (43)

(41) Statement made by reporter for the New York Herald Tribune, at Aspen Institute Berlin conference on April 18 20, 1986.

(42) For a general discussion of Advertising in transnational information transfers, see Primoff, L.R., "Transfer and Dissemination of Advertising Across National Borders", ch. 8 in Branscomb, supra Note 11.

(43) For a general discussion of Television across national boundaries, see Dunh- 


\section{Videotex and the Lander Treaty in Germany}

As we move into videotex (electronic publishing on a television screen or video monitor) we see the clash of the cultures as well as the law. Take, for example, the legal framework for press, mass media, and information transmission services (telephone, telegraph, microwave, satellites, cable, etc.) in the Federal Republic of Germany. The Lander, or state level of government, are prohibited from regulating news print but given exclusive jurisdiction over broadcasting: whereas the Deutsche Bundespost (DBP) has exclusive responsibility for the delivery of the mail and all "telecommunications services". Thus in the Bildshirmtext system, the DBP's entry into interactive videotex services, we find a clash of jurisdiction. The Lander wanted to take jurisdiction over what they deemed to be media services, since the central message was open and available to a large audience of viewers. However, it may also include an electronic message service-which can be legally defined to be "mail" and thus exclusively under the control of the DBP. Neither DBP nor the Lander would legally have jurisdiction over newspaper delivered electronically over the Bildschirmtext if it is defined to be like printed news.

Moreover, most of the broadcasting entities are now providing teletext services (one way videotex via television) over their transmitters. Although similar to the same services offered over an interactive videotex system, teletext but falls within the jurisdiction of the Lander as ancillary to broadcasting. The legal dilemma has resulted in a Treaty between the Lander concerning the offering of videotex. The Lander maintain authority over the content of the "mass media". However, the DBP does not accede to the validity of all of the provisions particularly concerning those related to "electronic mail"; and the treaty specifically excludes banking transactions which are covered by a different legal regime. ${ }^{(44)}$

\section{Computer bulletin boards}

The Germans do not seem to have experienced yet the new difficulty confronted within public computerized networks where individual messages are placed into a centralized computer discussion. In the United States discussion groups have arisen spontaneously within such public networks am \& Hering, "The Global Television Market", ch 7 in Branscomb, supra note 11 .

(44) Treaty on Bildschirmtext, 18 March 1983. 
as The Source or Compuserve. They are also encouraged by computer bulletin boards which are set up by individual computer owners who provide an interconnection to the public switched network through which their friends and professional colleagues or even strangers may enter their own messages. Here, truly nobody is in charge. Is the computer bulletin a new mass medium, public correspondece, a town meeting or a public forum? Some critics are concerned that too stringent controls upon systems will destroy a precious new mode of open public discussion. Others demand that someone be in charge of policing the messages for deleterious or prohibited messages such as proprietary software for downloading from the system to one's own computer or telephone charge account numbers. ${ }^{(45)}$

Thus each society, as it considers the advent of cable television, videtex, and ultimately the integrated services digital network (ISDN), will have to decide how much authority to allocate to which kinds of institutions within its society.

\section{F. International Issues}

\section{The General Agreement on Tariffs and Trade (GATT) (46)}

As information services and information products become more and more important to the local economy, the manner in which trade is negotiated in the international marketplace becomes more crucial. The GATT, the negotiated arrangement built up over the last 40 years for the exchange of manufactured goods, is now suggested as a possible regime for the promulgation of fair practices for marketing of telecommunications services. ${ }^{(47)}$

The telecommunications systems in most countries of the world are still integrally associated with the nation-state and the security of the people. In many countries the telecommunications system is operated by the military.

(45) Lasden, M., “Of Bytes and Bulletin Boards", New York Times Magazine, August 4, 1985, p. 34; Pollack, A., International Herald Tribune, November 28, 1984; Cambron, J., “A User's Guide to Bulletin Board Systems”, Portable 100, November 1983.

(46) For a general discussion of the applicability of GATT to telecommunications services and information products, see Herzstein, R.E., "Applying Traditional Trade Principles to the International Flow of Information", in Branscomb, supra note 11.

(47) “Toward a GATT for Services", International Services Updata, Washington, D.C.: U.S. Trade Representative, September 1922. 
Consequently there has been little public offering of telecommunications services in international trade. All that is changing as computers, satellites, and traditional telecommunications hardware join together to make possible "value added services" in which information is processed remotely. Also "on line" services are offered which move freely in a technical sense across national boundaries. At the same time these signals and services encounter legal obstructions which are intended to protect the integrity and security and availability of the telecommunications to nationals of the country which they serve.

There are a number of questions which arise in the context of applying GATT principles to information products, information transport (telecommunications) and information processing services.

a. Definition of "goods"

First comes the question whether such services and products are "goods" within the meaning of the GATT, since the GATT does not govern "services". (48) Some academics believe that information itself is a shareable resource which cannot enter into transactional relationships. ${ }^{(49)}$ However, it is quite clear that telecommunications services, like manufactured goods are offered to subscribers at a price based upon costs of providing the service. Although the system may have more capacity than required for the service intended, the use of the capacity involves a price which is negotiable and must cover the price of installation of the hardware and software necessary to engage in the information processing and delivery. Furthermore, information providers are investing both financial capital and intellectual capital into the production of their information products. They must, in order to survive in the information economy, be paid fair market value for their work product.

\section{b. "Reciprocity"}

Second is the question of "reciprocity" within the GATT framework. Reciprocity requires that a country seeking a right of entry into a market must provide an equivalent right of entry into its local market for the same

(48) Krommenacker, R., "Discussions on Services in GATT", Transnational Data and Communications Report, February 1986, p. 15.

(49) Cherry, C., A Second Industrial Revolution?; Machlup, F., The Production and Distribution of Knowledge in the United States, Princeton, NJ, Princeton Univ. Press 1962; Cleveland, H., The Knowledge Executive, New York, Dutton, 1985. 
product. However, the reciprocity concept ccnfounds the news media. Newspaper editors and broadcasters want a right of access to the source of news without providing a reciprocal right of access to the pages of their information product. Much of the dialog in the UNESCO has been based upon a perception by third world countries that treatment of the issues about them has not been balanced in the Western Press - thus there are substantial interests in disagreement over what would be considered "reciprocal". The news media, therefore, prefer to apply the principle of "free flow of information" which does not mean, of course, that they wish to give away their information products without compensation. ${ }^{(50)}$ It means that they want freedom of access to the sources of information.

\section{c. "National Treatment"}

Third, the principl of "national treatment" does not translate very happily into the parlance of news providers. British journalists do not want to be treated in the Soviet Union in the manner that the Soviets treat their own journalists but in the manner that they would be treated in London. They want to be treated on the basis of the national treatment of their own country of national origin.

Similarly, those seeking to provide "enhanced" or "value added" services in a new market do not seek national treatment in the country of destination. "Enhanced services" may not be permitted by the government or they may only be provided by the PTT through its national public networks. Information entrepreneurs want to be treated as a liberally as possible. Indeed, they want to establish a right of entry to offer "value added services" to whichever customers might decide to attach their own customer premises equipment to the "value added networks" which these entrepreneurs have pioneered. ${ }^{(51)}$ Domestic users also press for greater flexibility in harnessing the power of computers to their on communications and management needs.

\section{Extraterritorial jurisdiction}

Since it is more economically efficient for countries or companies with small computer access needs to obtain remote computing services offshore. Thus there may be sufficient internal pressure to persuade those who make policy to open up the domestic market for nondomestic suppliers. If economic

(50) Pool, I., Technologies of Freedom, Cambridge, MA, Belknap Press, 1983.

(51) Beach, S.H., and Marks, H.E., “Computer Services Industry Networks”, ch. 10 in Branscomb, ed., supra note 11 . 
efficiency is the primary concern, economies of scale and lower costs dictate the highest use of facilities wherever located. Computers which are active only eight hours of the twenty four hour day in one part of the world can be kept running efficiently by businesses operating in other parts of the world which are open during the remaining sixteen.

Global networking has become commonplace within airlines reservations systems (such as SABRE and SITA), ${ }^{(52)}$ in electronic funds transfer systems of the world banking community (SWIFT), and universities (BITNET, EARN and NORTHNET). ${ }^{(53)}$ A recent article in the NEW YORK TIMES describing the economic summit in Tokyo commented "The foreign exchange market, woven together by modern telecommunications, has grown into an increasingly volatile $\$ 150$ billion-a-day behemoth that hardly notices national borders." (54) However, that is merely the tip of the iceberg. The Mormon Church has one of the largest telecommunications systems in the world through which Mormons are linked internationally to the mother church in Salt Lake City. The Vatican also has a substantial multimedia network to reach Catholics.

Thus the nation-states which seek to enter the information society, must be cognizant of the sometimes overriding interests of these transnational groups which must work within the legal system of a given national state or many nation states but have interests which do not necessarily coincide with the cultural mandates of the host country. Similarly, multinational companies, some of which have greater economic resources than many nation states must operate in wide environment in which they must conform to the many different legal requirements of their host or national systems.

Increasingly such companies are working together in joint ventures such as AT\&T/Lucky-Goldstar Group, Mitsubishi/Westinghouse, GE/Fujitsu, ATT/Olivetti, Fuji/Xerox, and ITT/Siemans. Such joint ventures, as well as wholly owned subsidiaries operating solely with nationals of the country of operation, cloud the issue of nationality of such business operations. What is the extraterritorial reach of national laws to entities which are nominally

(52) "Sita: A Worldwide Telecommunications Service for Airlines", PTC Quarterly, December 1985.

(53) For a discussion of legal issues related to educational networks see McCredie, J.W. \& Timlake, W.P., “Evolving Computer Networks in American Higher Education", ch. 14 in Branscomb, supra note 11.

(54) New York Times, Sunday, May 4, 1986, p. $10 f$. 
but not practically within the jurisdiction of the legal instruments of a host nation?

\section{Access to data stored outside the country of origin}

Maintenance of data outside the nation of origin creates another problem concerning rights of access to data stored in another country. In times of peril, or public distress, or unacceptable behavior on the part of the state of origin the host nation may seek to impound the data (especially if it is in the form of bank drafts of critical economic data).

The legal concept which is called "vulnerability" was discussed at length by the Swedes who became concerned when access to the Malmo fire department's data was blocked by a computer breakdown in Columbus, Ohio. ${ }^{(55)}$. More recently, the Bank of Montreal was treated to two different legal regimes when a Miami, Florida, court subpoenaed bank records of its subsidiary in the Cayman islands. The local laws of the Cayman islands required nondisclosure of such information. ${ }^{(56)}$ How do we reconcile the tripartite legal treatment of such information? Here we have a question af economic and security interests in conflict? Equally important is the question of what constitutes illegal behavior in the transport and processing of information. This is an area in which the OECD has done a substantial work attempting to ascertain how to harmonize criminal laws. ${ }^{(57)}$

Arthur Bushkin has suggested that there will be increasing pressure from companies as well as smaller countries which use offshore data bases for a legally enforceable principle of international law guaranteeing access to data processed in other countries and a guarantee that unilateral action cannot block access. ${ }^{(58)}$ This should be especially important to banks operating in a number of countries. It may not be so palatable to taxing authorities who see non national banks as a data haven for funds seeking to avoid national

(55) Ministry of Defense (Sweden), The Vulnerability of a Computerized Society (1979).

(56) United States v. Bank of Nova Scotia, (BNS 1) 69 F. 2d 1184 (11th Cir. 1982); "Socialbank Caught Between Two Sets of Laws", The Citizen, Ottawa, November 16, 1983; Burnett, John T., "Information, Banking Law and Extraterritoriality", Transnational Data and Communications Report, January 1986, p. 17-18.

(57) Private Communication from Peter Robinson. Documents related to the OECD study on criminal liability should be issued in 1986 .

(58) Speech at Worldcom/84, September 14, 1984. 
taxation.

Such a principle of public international law might be drafted to protect proprietary data processed or stored within or in transit through another country so long there is no breach of the law of either the host or the originating country. Certainly nations, individuals, or companies originating the data outside the host country will seek some legally enforceable rights of ingress and egress into such offshore data bases. Otherwise, an internationally efficient information marketplace cannot be maintained.

\section{The International Telecommunication Union(ITU)}

The Communications environment is itself a forum in which differences are mediated. Thus the integrity and honesty and openness of that environment is crucial to governance. Thomas Ramsey, who negotiated the improvements in the "hotline" between the the leaders of the U.S. and the USSR, spoke of the dedication of the professionals, the technicians who were working hard to make this system function effectively. They were shocked to discover that their countries maintained a legal right to cut the connection between the two telephones. Regardless of their personal, political differences and that of their nations, they wanted the telecommunications system to be available, especially in times of international crises and they were dedicated to that end. ${ }^{(59)}$

Notwithstanding our cultural differences, we must build and protect a functioning global communications network. Regardless of whether such system consists of a public switched ISDN, a cooperative of many ISDNs or a complex system of competing networks, they must be interconnected so that the global dialog can continue. Global information exchange is critical to international finance. Cultural exchange in an age of great mobility of ethnic groups is essential to protect diversity of choice. The ability to monitor weather, environmental pollution, nuclear accidents, and terrorists activities is crucial to national and international security. Therefore, it is imperative that all nations cooperate to develop, improve, and protect the information infrastructure as the crucible through which international cooperation can occur and cultural clashes be mediated.

The dictates of a global economy, global security, and global cultural exchange suggest that the time is past when nation states should have a legal

(59) Lecture at Polytechnic University of New York, April 12, 1986. 
right to "unplug" from the global network. Article 19 of the ITU convention protects such right on the part of all nations. Ironically, it is substantially at odds with Article 19 of the Universal Declaration of Human Rights which proclaims a basic right to communicate across national frontiers. Such a right is still emerging as an ethical mandate ${ }^{(60)}$, as there are few sanctions for enforcement other than the power of public opinion.

\section{G. Conclusions}

A major trend in an information society is that hierarchical bureaucracies become obsolete. Thus the government leaders and business managers are confronted with a citizenry and labor force which has greater access to information, indeed, may be overwhelmed by information overload. Nobody is truly in charge, since the leaders can lead only in the direction that their constituencies are willing to follow. Alternatively, they must struggle to stay ahead of where their constituencies are pushing them to go.

Additional pressure is put on the educational system to prepare nationals for citizenship in a global society where they will be pelted with ideas, facts, figures and cultural influences from many sources. To cope they must develop the skills of analysis, group discussion, negotiation, and persuasion. In a global information society the means for international accommodation come through the mass media and private exchanges from person to person, or group to group, across national boundaries. Information sources provide conflicting and sometimes mutually exclusive points of view. Nation-states can protect themselves from outside influences only through the most stringent domestic controls, which are unacceptable in most corners of the globe. Therefore, the ability to argue persuasively in this open information environment is critical to survival.

(60) For a discussion of the Right to Communicate asserted as a legal right, see Cocca, A.A., El Derecho a Communicarse, Buenos Aires, Argentina, Consejo de Estudios Internacionales Avanzadas, 1983; Tonkin, H., "A Right to International Communication?”, ch. 10 in Gerbner \& Seifert, ed., World Communications, White Plains, NY: Longman, 1983; Feldman, M., "The Right to Communicate Under International Law”, ch. 27 in Branscomb, supra note 11. Harms, L. et al., Right to Communicate: Collected Papers, Honolulu, HI, Univ. of Hawaii Social Sciences and Linguistics Institute, 1977; d'Arcy, $\mathrm{J}$, "Le droit de l'homme a communiquer", Commission International d'etude des problems de la communications, no. 36, Paris: UNESCO. 
Governance by coercion no longer works except by imposing unacceptable economic consequences. As a consequence governance by persuasion is our only alternative. This results in multiple legal concerns:

-Should there be some legally enforceable right to communicate both within a nation state and across national boundaries?

- Should there be a legally enforceable right to access to the information upon which public decisions must be based regardless of location?

- Should there be a legally enforceable obligation to disclose information upon which public decisions rest?

To the extent that a society: a) fails to invest in its information transport system, (b) neglects the education of its children, (c) engages in protective trade barriers, (d) closes its borders to outside influences, (e) enacts import quotas, ( $f$ ) imposes restriction on the circulation of information, and ( $g$ ) does not compensate intellectual productivity fairly, it is rejecting the path toward an information society as well as active participation in a global economy.

It is in the legal infrastructure for the new videotex services and satellite broadcasting that we will see the foundations of a global information society emerge. As videotex is a new information form, it does not carry the inhibitions of established legal principles to which many are wedded philosophically. These messages are transmitted via satellites and computers which transcend the territorial boundaries of nation states. They impose imperatives which command that sovereign states relinquish a little of their sovereignty in order to participate in the economic wealth which flows from the spread of information technology.

In summary, an information society must redefine work to include the basic ingredients of the information society-the gathering, processing, distribution, and archiving of information in all of its many forms. It must recognize that education is a primary industry. It must welcome all citizens into full participation in public deliberations. It must help build a global communications system which can accommodate the diversity of cultural communities which inhabit this planet.

A global economic system is emerging in which the technological imperative for cooperative arrangements is strong. Respect for individual national and cultural differences must prevail over group conformity. Cooperation must emerge as the tactic of choice over confrontation, and consensus must replace coercion as the tool of choice for the resolution of disputes. 
In the information society, information itself will become the instrument of persuasion through which global harmony can be achieved and information transport systems will become the environment within the cultural differences are mediated. 